\title{
THE EFFECTS OF FEE SHIFTING ON THE SETTLEMENT RATE: THEORETICAL OBSERVATIONS ON COSTS, CONFLICTS, AND CONTINGENCY FEES
}

\author{
John J. Donohue, III*
}

\section{INTRODUCTION}

A large and growing literature in law and economics analyzes, from an economic perspective, the decision to initiate litigation and the subsequent decision to settle the dispute or proceed to trial. ${ }^{1}$ Rather simple models yield predictions that are frequently both precise and counterintuitive-two highly attractive elements of the academician's enterprise. ${ }^{2}$

My own initial foray into this field came from a rather unconventional perspective. In a previous article, I demonstrated that bonus payments offered by the state of Illinois to unemployment compensation recipients who quickly returned to work could be analogized to bribes paid to encourage

Copyright (C 1991 by Law and Contemporary Problems

* Professor of Law, Northwestern University School of Law; Research Fellow, American Bar Foundation.

I would like to thank Ian Ayres and Peter Siegelman for their helpful comments and Kirsten Alesch Muth for excellent research assistance.

1. Among the important contributions are William M. Landes, An Economic Analysis of the Courts, $14 \mathrm{~J} \mathrm{~L}$ \& Econ 61 (1971); Richard A. Posner, An Economic Approach to Legal Procedure and Judicial Administration, $2 \mathrm{~J}$ Legal Stud 399 (1973); Richard A. Posner, Economic Analysis of Law $\$ 215$ at 522 (Little, Brown, 3d ed 1986); John P. Gould, The Economics of Legal Conficts, 2 J Legal Stud 279 (1973); George L. Priest, Regulating the Content and Volume of Litigation: An Economic Analysis, $1 \mathrm{~S}$ Ct Econ Rev 163 (1982); George L. Priest \& Benjamin Klein, The Selection of Disputes for Litigation, $13 \mathrm{~J}$ Legal Stud 1 (1984); Steven Shavell, Suit, Settlement, and Trial: A Theoretical Analysis under Alternative Methods for the Allocation of Legal Costs, II J Legal Stud 55 (1982); Robert D. Cooter, Stephen Marks \& Robert Mnookin, Bargaining in the Shadow of the Law: A Testable Model of Strategic Behavior, $11 \mathrm{~J}$ Legal Stud 225 (1982); I.P.L. P'ng, Strategic Behavior in Suit, Settlement, and Trial, 14 Bell J Econ 539 (1983); Geoffrey P. Miller, An Economic Analysis of Rule 68, 15 J Legal Stud 93 (1986); John C. Hause, Indemnity, Settlement, and Litigation, or I'll Be Suing You, $18 \mathrm{~J}$ Legal Stud 157 (1989). For an excellent survey, see Robert D. Cooter \& Daniel Rubinfeld, Economic Analysis of Legal Disputes and Their Resolution, $27 \mathrm{~J}$ Econ Lit 1067 (1989).

2. As Judge Posner has stated: "The big thing is to come up with hypotheses that have a sufficiently low antecedent probability of being true to be interesting, but that are not so ridiculous that the results of testing them empirically are a foregone conclusion, and to get on with the testing of them." Richard Posner. The Future of Law and Economics: A Comment on Ellickson, 65 Chi-Kent L Rev 57,61 (1989). 
faster reemployment of unemployed workers. $^{3}$ The Illinois experiment proved to be a useful vehicle with which to analyze the Coase Theorem, ${ }^{4}$ because in the absence of transaction costs it should not matter whether the state of Illinois offered the bonus to workers or to their employers. Where the size of the bribe is equal, the same incentive to contract should exist under either assignment of the bonus. ${ }^{5}$

The analogy of the bribe is also potentially useful in the litigation context, because litigation costs could be conceived as a bribe to parties to reach a contractual agreement settling their dispute. ${ }^{6}$ This immediately raises the question of what effect fee-shifting rules might have on settlement rates. Since the Coase Theorem implies that legal rules will not matter when the parties can costlessly contract around them, it would seem that with zero transaction costs the rate of settlement-that is, the rate of contracting to avoid the cost of litigation-should be identical regardless of the legal rule concerning who bears the costs of litigation. ${ }^{7}$ I was therefore quite intrigued to learn from Judge Posner that "making the losing party pay the winning party's attorney's fees would reduce, not increase, the settlement rate." 8 Moreover, the fact that only a few years earlier Judge Posner had expressed the exact opposite conclusion-making the losing party reimburse the winning party for his litigation expenses would increase the rate of settlement ${ }^{9}$-added to the intrigue. My fascination grew as the latest contributions to this literature by Hause ${ }^{10}$ and Hersch ${ }^{11}$ asserted that Posner had it right the first time, but for the wrong reasons.

My goal in this paper is to provide some coherence to this fractured literature. Part II begins by exploring why a degenerate Coasean analysis of the impact of fee-shifting statutes is inadequate and a richer Coasean analysis was overlooked. Part III further analyzes the conflicting assessments of the effect of fee-shifting, focusing on the extent to which adoption of the British rule will lead to higher litigation expenditures. Part IV builds upon the earlier discussion by analyzing the decision to settle or litigate when the litigation is pursued under a contingency fee arrangement between the plaintiff and his attorney. Once again, the direct and indirect effects of fee-shifting will be examined, but in the contingency fee context. Finally, Part $\mathrm{V}$ will offer

3. John J. Donohue, Diverting the Coasean River: Incentive Schemes to Reduce Unemployment Spells, 99 Yale L J 549 (1989).

4. The Coase Theorem implies that legal rules will have no effect on ultimate outcomes because parties will reach identical, efficient outcomes as long as they are free to bargain costlessly and there are no wealth effects associated with the assignment of the legal entitlement. Ronald $\mathrm{H}$. Coase, The Problem of Social Cost, 3 J L \& Econ 1 (1960).

5. Donohue, 99 Yale L J at 553 (cited in note 3).

6. Id at $567 \mathrm{n} 49$.

7. This argument is set forth in detail in John J. Donohue, Opting for the British Rule, or If Posner and Shavell Can't Remember the Coase Theorem. Who Will?, 104 Harv L Rev 1093 (1991).

8. Richard A. Posner, Comment on Donohue, 22 L \& Society Rev 927, 928 (1988).

9. Posner, $2 \mathrm{~J}$ Legal Stud at $\mathbf{4 2 8 - 2 9}$ (cited in note 1 ).

10. Hause, $18 \mathrm{~J}$ Legal Stud at 158 (cited in note 1).

11. Philip L. Hersch, Indemnity, Settlement, and Litigation: Comment and Extension, $19 \mathrm{~J}$ Legal Stud 235 (1990). 
theoretical observations about the effect on the settlement process from the timing of litigation expenditures and the size of a given settlement range. I will also comment on the relevance of these issues on settlements in mass tort litigation.

\section{The Coase Theorem and the Rate of Settlement}

The simplest economic analysis of the fee-shifting question might proceed as follows. Assume both parties realize that a trial will be costly and that total wealth will therefore be maximized by avoiding the trial. Given a zerotransaction cost world, the parties will agree to a mutually wealth-maximizing solution and will reach some accord on the distribution of the surplus. Therefore, all cases will settle regardless of whether the case is governed by the British rule, under which the losing party pays both parties' legal fees, or the American rule, which presumes that, regardless of outcome, each party shoulders his or her own legal expenses.

This point can be illustrated somewhat more formally as follows. Assume that plaintiff A sues defendant B for a specific amount $D$ in an American-rule jurisdiction. If the case goes to trial, the plaintiff's costs will be $C_{\mathrm{A}}$ and the defendant's costs will be $C_{\mathrm{B}}$. Where $P$ is the probability that the plaintiff will prevail at trial, the expected benefit to the plaintiff and the expected cost to the defendant of going to trial are given by

(1) $E B_{\mathrm{A}}=P^{*} D-C_{\mathrm{A}}$, and

(2) $E C_{\mathrm{B}}=P^{*} D+C_{\mathrm{B}}$.

Since settlements are expected whenever $E B_{\mathrm{A}}<E C_{\mathrm{B}}$, settlements should occur whenever

(3) $P^{*} D-C_{\mathrm{A}}<P^{*} D+C_{\mathrm{B}}$, or equivalently,

(4) $0<C_{\mathrm{A}}+C_{\mathrm{B}}$, which is always true for positive litigation costs. In other words, when both parties agree on the likely outcome at trial (in this example, $P^{*} D$ ), all cases will settle. Inequality (4) also governs the case of litgation conducted under the British rule.

This degenerate application of the Coasean invariance prediction is quite unappealing since we know that not all cases settle. To avoid this obvious pitfall, Posner and Shavell argue that if parties insist on clinging to their differing assessments of the probability of success, this simple invariance prediction breaks down. ${ }^{12}$ If plaintiff believes he will win at trial and defendant is certain that plaintiff will lose, there is no basis for settlement unless legal fees are quite high. ${ }^{13}$ Therefore, one should not expect all cases to settle. The socially efficient solution will not be the privately efficient solution. More importantly, under the British rule, substantial optimism about one's case tends to shrink the size of the "bribe" to settle, because the

12. Posner, Economic Analysis of Law $\S 21.5$ at 522 (cited in note 1); Shavell, $11 \mathrm{~J}$ Legal Stud at 6366 (cited in note 1 ).

13. This will be demonstrated more formally in Part IIB of this article by inequality (10). 
victorious party need not bear his legal fees. Thus, according to Posner and Shavell, settlement rates will be affected by the rules concerning fee allocation. ${ }^{14}$

But the analysts quit too soon. The Coase Theorem is not so easily derailed as Posner and Shavell assumed. We can preserve the Coasean outcome of equal settlement rates while avoiding the obviously erroneous prediction that all cases will settle. The Coase Theorem would be a weak proposition if it could be thwarted simply by differing expectations among the parties. Indeed, whether one explores a customary Coasean example, such as the case of a polluting firm discussed below, or the litigate/settle question, contracting mechanisms exist to preserve the Coasean invariance prediction in a zero transaction cost setting.

\section{A. The Pollution Hypothetical}

Consider the oft-used example of a steel company's pollution that damages agricultural crops. Acme Steel Company engages in steel production that emits a certain amount of smoke and particulate matter. The emissions may adversely affect nearby crops owned by the Beatrice Company. Does it matter whether Acme has the right to pollute or Beatrice has the right to be free from pollution? By now, the answer is familiar to virtually all legal academics: in the absence of transaction costs, the Coase Theorem tells us that the allocation of resources will not be affected by the initial assignment of the legal entitlement. ${ }^{15}$ In other words, the same amount of pollution and steel will be produced regardless of whether the law gives the right to pollute to Acme or the right to be free from pollution to the farmer.

Assume that both Acme and Beatrice are profit-maximizing firms that weigh the expected costs and benefits resulting from Acme's production of steel and the concomitant product, pollution. $E B_{\mathrm{A}}$ is the expected benefit to Acme from producing steel (and pollution). Presumably, Acme and Beatrice have expectations about the probability that the pollution will damage the crops, causing an economic loss of $D .{ }^{16}$ These probabilities are denoted by $P_{\mathrm{A}}$ and $P_{\mathrm{B}}$. To explore the operation of the Coase Theorem in this context, consider two cases: (1) Acme possesses the right to pollute, and (2) Beatrice's entitlement to be free of pollution is protected by a liability rule. ${ }^{17}$

1. Acme Owns the Entitlement. Beatrice would be willing to bribe Acme not to pollute if the following condition holds:

(5) $E B_{\mathrm{A}}<P_{\mathrm{B}}{ }^{*} D$.

14. Posner, Economic Analysis of Law $\S 21.5$ at 522 (cited in note 1); Shavell, 11 J Legal Stud at 6366 (cited in note 1 ).

15. See note 4 for an explanation of the Coase Theorem.

16. Another example where a firm might act with certainty that there is risk of damage but without perfect knowledge of the probability of damage is the use of asbestos in hair dryers.

17. A third case-Beatrice owning an entitlement protected by a property rule-can be readily analyzed in a similar manner. 
This inequality merely reiterates that if the expected benefit to Acme from polluting is less than the expected cost to Beatrice, then Beatrice can offer a bribe to Acme to forego polluting that is greater in value than Acme's profits from polluting.

2. Beatrice Owns the Entitlement. Since Beatrice is entitled to be free of Acme's pollution, and this right is protected by a liability rule, Acme will have to pay damages to Beatrice if Acme generates pollution. Therefore, Acme will produce the pollution only if the expected benefits are greater than the expected damages. Conversely, Acme will curtail the pollution if the expected benefits of polluting are less than Acme's estimate of the expected harm suffered by Beatrice $\left(=P_{\mathrm{A}}^{*} D\right) .{ }^{18}$ In summary, it would appear that the pollution will be curtailed if the following condition holds:

(6) $E B_{\mathrm{A}}<P_{\mathrm{A}}^{*} D$.

Note that inequalities (5) and (6) are identical only in the unlikely circumstance that the parties have equal estimates of the probability of harm. Therefore, at first glance it would seem that the legal rule regarding entitlement will affect the amount of steel production and pollution, and the Coase Theorem fails. For example, consider the case in which Acme has the right to pollute, its expected benefit from polluting is $\$ 500$, and Beatrice's estimate of the expected harm it will suffer equals $\$ 550 .^{19}$ In this event, inequality (5) holds, and the pollution will be curtailed because Beatrice will pay a bribe to stop it. But if Beatrice holds the entitlement protected by a liability rule and Acme's estimate of the expected harm is only $\$ 400,{ }^{20}$ then inequality (6) will not hold. Acme would be happy to pollute to enjoy the expected benefits that exceed the expected damages. In other words, it seems that the legal rule matters.

But this analysis is incomplete. If Acme owns the right to pollute and is confident in its estimate of the expected damage, it can profit by refusing Beatrice's bribe to stop the pollution. Instead, Acme will sell to Beatrice-for, say, $\$ 500$ - a promise to indemnify it for any pollution loss. This indemnity agreement would be an ex ante Pareto optimal contract for both parties given their respective estimates of the expected harm caused by the pollution. ${ }^{21}$

18. Assume the parties will comply with all legal rules, so that if Acme's pollution causes $D$ in damage to Beatrice when the latter is protected by a liability rule, Acme will pay $D$ to Beatrice without requiring Beatrice to resort to litigation.

19. Assume Beatrice's estimate of $P_{\mathrm{B}}$ equals .55 and its dollar estimate of $D$ is $\$ 1,000$. Beatrice's estimate of the expected harm then equals $P_{B}^{*} D=.55 * \$ 1,000=\$ 550$.

20. Assume Acme's estimate of $P_{A}$ is .40 and $D$ remains $\$ 1,000$. Acme's estimate of the expected harm then is $P_{\mathrm{A}} * D=.40 * \$ 1,000=\$ 400$.

21. A contract is Pareto efficient when it allocates resources such that there is no other productively feasible allocation that results in all parties to the contract being at least as well-off, and at least one party strictly better off, than they were originally. John Eatwell, Murray Milgate \& Peter Newman, eds, 3 The New Palgrave Dictionary of Economics 811 (Macmillan, 1987). Since Acme owns the right to pollute, it could simply produce the steel and earn $\$ 500$ while imposing a pollution loss on Beatrice. By accepting the $\$ 500$ from Beatrice while assuming the responsibility of holding Beatrice harmless, Acme will earn $\$ 1000$ minus the expected pollution damage of $\$ 400$. This $\$ 600$ return is higher than his alternatives of earning (1) $\$ 500$ if it pollutes or (2) something less than $\$ 550$ if it 
This discussion illustrates that, as a general matter, differing expectations are not enough to undermine the Coase Theorem. With zero transaction costs, the parties in the pollution hypothetical will face the same incentive to move to the ex ante efficient outcome regardless of the legal rule. The bribe that serves as the inducement for them to do so is the expected profit of $\$ 100$ that results if Acme's predictions are correct, and this expectation will not be altered by the legal rule. ${ }^{22}$

\section{B. The Symmetrical Litigation Hypothetical}

One can analyze the settlement question in a fashion quite similar to the above analysis of the pollution hypothetical. Assume that the parties disagree on the probability of a plaintiff's verdict, so that the plaintiff's estimate $\left(P_{\mathrm{A}}\right)$ is not equal to the defendant's estimate of the probability of a plaintiff's verdict $\left(P_{\mathrm{B}}\right)$. I will reexamine the two fee assignment regimes making only this change in the parties' estimates of the probability of the plaintiff's success. Posner ${ }^{23}$ and Shavell ${ }^{24}$ concluded using this same analysis that the legal rule on fee assignment would alter the settlement rate.

\section{The American Rule}

The expected net benefit to the plaintiff and the expected cost to the defendant of going to trial are given by

(7) $E B_{\mathrm{A}}=P_{\mathrm{A}}^{*} D-C_{\mathrm{A}}$, and

(8) $E C_{\mathrm{B}}=P_{\mathrm{B}}^{*} D+C_{\mathrm{B}}$.

The added variables $C_{\mathrm{A}}$ and $C_{\mathrm{B}}$ represent A's and B's litigation costs.

Since settlements are expected whenever $E B_{\mathrm{A}}<E C_{\mathrm{B}}$, the condition for settlements occurs whenever

(9) $P_{\mathrm{A}}^{*} D-C_{\mathrm{A}}<P_{\mathrm{B}}^{*} D+C_{\mathrm{B}}$, or, equivalently,

(10) $P_{\mathrm{A}}-P_{\mathrm{B}}<\left(C_{\mathrm{A}}+C_{\mathrm{B}}\right) / D$.

The British Rule

The requirement that the losing party pays the legal costs of both parties will affect the expected costs and benefits of trial. Specifically, each party's expected trial costs simply will be its estimate of the probability of losing- (1$P_{\mathrm{A}}$ ) for the plaintiff, $P_{\mathrm{B}}$ for the defendant-multiplied by the sum of $C_{\mathrm{A}}$ and $C_{\mathrm{B}}$ :

(11) $E B_{\mathrm{A}}=P_{\mathrm{A}}^{*} D-\left(1-P_{\mathrm{A}}\right)\left(C_{\mathrm{A}}+C_{\mathrm{B}}\right)$, and

(12) $E C_{\mathrm{B}}=P_{\mathrm{B}}^{*} D+P_{\mathrm{B}}\left(C_{\mathrm{A}}+C_{\mathrm{B}}\right)$.

accepts a bribe from Beatrice to stop polluting. At the same time, Beatrice will lose $\$ 500$, which is the minimum bribe that it would have needed to pay Acme to stop polluting.

22 . See note 21 for calculation of the $\$ 100$ expected profit. In fact, it can be shown that, as long as either party believes that the expected pollution damage will be less than the expected gain from producing steel, the parties will contract in such a way as to ensure that the steel and the pollution are produced. I refer to this as the pollution paradox, which basically testifies to the power of profits. See John J. Donohue, The Pollution Paradox and the Power of Profits (unpublished manuscript, 1990). Therefore, the legal rule will not make a difference: the production will always take place when either party's expectations make it appear profitable.

23. Posner, Economic Analysis of Law $\$ 21.5$ at 522 (cited in note 1). The second edition of Economic Analysis of Law first presented Posner's revision of his 1973 analysis, found in Posner, $2 \mathrm{~J}$ Legal Stud at 428-29 (cited in note 1).

24. Shavell, $11 \mathrm{~J}$ Legal Stud at 63-66 (cited in note 1). 
Once again, the condition for settlements is that $E B_{\mathrm{A}}<E C_{\mathrm{B}}$, or

(13) $P_{\mathrm{A}}^{*} D-\left(1-P_{\mathrm{A}}\right)\left(C_{\mathrm{A}}+C_{\mathrm{B}}\right)<P_{\mathrm{B}}^{*} D+P_{\mathrm{B}}\left(C_{\mathrm{A}}+C_{\mathrm{B}}\right)$, and

(14) $P_{\mathrm{A}}-P_{\mathrm{B}}<\left(1-P_{\mathrm{A}}+P_{\mathrm{B}}\right)\left(C_{\mathrm{A}}+C_{\mathrm{B}}\right) / D$.

Since inequalities (10) and (14) differ on the right hand side, it is clear that, when $P_{\mathrm{A}}$ and $P_{\mathrm{B}}$ are not equal, the conditions for settlement are different under the American and British rules.

If we make use of the stylized fact that total costs are roughly half of the total damages in tort litigation, ${ }^{25}$ we can greatly simplify the interpretation of these conditions. Substituting this cost ratio into the previous two conditions yields the following conditions:

The American Rule

(15) $P_{\mathrm{A}}-P_{\mathrm{B}}<.5$

The British Rule

(16) $P_{\mathrm{A}}-P_{\mathrm{B}}<\left(1-P_{\mathrm{A}}+P_{\mathrm{B}}\right) * .5$, which is equivalent to

(17) $P_{\mathrm{A}}-P_{\mathrm{B}}<.33$.

Under both legal regimes, if the plaintiff is less optimistic than the defendant about the plaintiff's chance of success-that is, $P_{\mathrm{A}}<P_{\mathrm{B}}$-then the case will always settle because conditions (15) and (17) hold. Thus, we need only concern ourselves with the case where $P_{\mathrm{A}}>P_{\mathrm{B}}$. Inequality (15) indicates that, under the American system, the difference between plaintiff's and defendant's estimate of plaintiff's probability of success at trial will have to exceed .5 before a trial will occur. Inequality (17) reveals that, under the British system, the range of disagreement within which settlement will occur shrinks to only .33 .26 In other words, as Posner and Shavell have stressed, one would expect the rate of settlement to fall if the United States were to adopt the British rule on fee shifting and if the parties cannot or do not contract for the preferred rule of fee allocation.

But as we saw in the pollution hypothetical above, parties are free to contract around legal rules and might be expected to do so when it is to their advantage. In the litigation context, the introduction of differing probabilistic assessments requires more complex contracting to preserve the Coasean outcome. As I have shown elsewhere, the parties will be able to evaluate how well they will do at trial under both the American and British rules. ${ }^{27}$ Then they can shift to whichever rule increases their expected wealth. Whenever the Posner/Shavell analysis suggests that settlement would be possible under

25. In other words $\left(C_{\mathrm{A}}+C_{\mathrm{B}}\right) / D=.5$. See James S. Kakalik \& Nicholas M. Pace, Costs and Compensation Paid in Tort Litigation 69-70 (RAND, 1986); Patricia M. Danzon \& Lee A. Lillard, The Resolution of Medical Malpractice Claims: Research Results and Policy Implications vii (RAND 1982) (claiming that, in medical malpractice suits, total litigation costs roughly equal compensation received by the plaintiff).

26. The set of combinations of $P_{\mathrm{A}}$ and $P_{\mathrm{B}}$ that will generate a settlement range necessarily shrinks because, with one exception, the term $\left(P_{\mathrm{A}}-P_{\mathrm{B}}\right) /\left(1-P_{\mathrm{A}}+P_{\mathrm{B}}\right)$ is necessarily greater than the term $P_{\mathrm{A}}-P_{\mathrm{B}}$ for all possible probabilities. The single exception is when $P_{\mathrm{A}}-P_{\mathrm{B}}=1$, and therefore division by zero is impermissible. In this case, which implies that $P_{\mathrm{A}}=1$ and $P_{\mathrm{B}}=0$, no possibility of settlement exists under either the American or British rules given the level of trial costs assumed in this example.

27. Donohue, 104 Harv L Rev at 1093 (cited in note 7). 
the American rule but not under the British rule, the parties can contract to try the case under the British rule. ${ }^{28}$ In this case, both parties will perceive that such a rule-shifting contract will enhance their expected wealth. Thus, the Coasean outcome will be preserved since the assessment of the best rule for fee allocation will not depend on whether one resides in an American-rule or British-rule jurisdiction. ${ }^{29}$

\section{III}

\section{Does the Rule of Law Change the Costs of Litigation?}

Thus far, we have seen that the Posner/Shavell analysis of the settlement decision evaded the unattractive conclusion that all cases would settle and indicated that the British rule would lead to fewer settlements. With costless contracting, however, parties could opt for the superior cost-allocation rule in the manner predicted by the Coase Theorem. If transaction costs are low enough and parties are aware enough to act in this fashion, we might expect to see equal settlement rates under the two cost-allocation regimes. But since there is virtually no evidence that parties in litigation do contract to try cases under a different rule of cost-allocation than that which prevails in their jurisdiction, it may make sense for the moment to put aside the global Coasean challenge to the Posner/Shavell model, and to consider two internal critiques. The discussion that follows will therefore adhere to the assumption that litigants are bound by their jurisdiction's fee allocation rules.

\section{A. The Hause Critique}

The discussion heretofore has assumed that the amount of money expended by both parties in litigation would not be altered by a shift from the American rule to the British rule. Hause has pointed out, though, that parties would tend to expend more on a trial under the British system because more is at stake in the litigation. ${ }^{30}$ The basic argument asserts that under the American rule parties will expend money on litigation to the point where the marginal benefit, given by $D$ times the increase in the probability of success caused by the last dollar spent on litigation, equals the marginal cost. But under the British rule, the expected gain of additional spending on litigation is greater $^{31}$ and the expected cost is less ${ }^{32}$ than under the American rule.

28. Id. Optimistic litigants have a smaller incentive to settle under the British rule because they each believe the other party will likely bear trial costs.

29. If plaintiffs in a certain context systematically over-valued their likelihood of success, thereby unreasonably diminishing the chance for settlement, the British rule might ultimately serve the didactic function of making the agony of defeat somewhat more painful. This position would do nothing, though, to increase the reliability of judgments in the immediate case, although it might improve future decisionmaking.

30. Hause, $18 \mathrm{~J}$ Legal Stud at 167 (cited in note 1).

31. Under the American system, the benefit of enhancing the probability of success equals the change in probability times $D$. Under the British system, the benefit also includes the change in probability times total litigation costs. 
These factors will induce higher litigation expenses by both parties under the British rule.

To illustrate the greater stakes under the British rule, assume that plaintiff's expenses are one-third the amount in controversy $(.33 D)$ and defendant's expenses are one-sixth the amount in controversy (.17D).$^{33}$ This would imply that under the American rule a plaintiff would risk losing $.33 D$ (33 percent of $D$ ) in bringing a lawsuit and hope to gain $.67 D$ (67 percent of $D$ ), while the defendant would hope to lose only .17D (17 percent of $D$ ) but would be at risk to lose $1.17 D(117$ percent of $D)$. Accordingly, the amount at stake for both parties is $D$. Under the British rule, however, a plaintiff would risk losing $.5 D$ (50 percent of $D$ ) and would hope to gain $D$, while the defendant would hope to lose nothing, but would be at risk to lose $1.5 D$ (150 percent of $D$ ). In this case, the amount at stake has risen to $1.5 D$ for both parties. This change certainly should lead to an increase in the legal resources devoted to the litigation by the two parties. Since, as we have stressed, litigation costs serve as a bribe to settle the case, the fact that legal costs rise under the British rule is potentially significant because this will increase the size of the bribe. The question, then, is whether this increase in litigation expenses will offset the tendency identified by Posner and Shavell for parties under the British rule to have lower expected litigation costs since the winning party's costs are paid by the losing party.

\section{B. The Critique of Hause}

In considering this question, reflect again on the conditions for settlement under the two rules given the previous assumption that total litigation costs equal $.5 D$ (50 percent of $D)$ :

The American Rule

(18) $P_{\mathrm{A}}-P_{\mathrm{B}}<.5$

The British Rule

(19) $P_{\mathrm{A}}-P_{\mathrm{B}}<\left(1-P_{\mathrm{A}}+P_{\mathrm{B}}\right) * .5$, which is equivalent to

(20) $P_{\mathrm{A}}-P_{\mathrm{B}}<.33$.

We must now modify inequality (20) to account for the increase in litigation expenses. Let $Q$ equal the proportionate increase in total litigation costs in moving from the American to the British rule. This modification implies that if costs are given by $C$ under the American rule, then they will be given by $C(1+Q)$ under the British rule. These modifications suggest the following condition for settlement under the British rule:

(21) $P_{\mathrm{A}}-P_{\mathrm{B}}<\left(1-P_{\mathrm{A}}+P_{\mathrm{B}}\right) * C(1+Q) / D$, which is equivalent to

(22) $P_{\mathrm{A}}-P_{\mathrm{B}}<\left(1-P_{\mathrm{A}}+P_{\mathrm{B}}\right) * .5(1+Q)$ since $C / D=.5$.

32. The expected cost of spending an additional dollar on litigation under the American rule is exactly one dollar. Under the British rule, you may get the dollar back if you succeed at trial, so the expecied cost is only $(1-P)$, where $P$ is the probability of victory at trial.

33. Thus, total expenses are $.5 \mathrm{D}(50 \% * \mathrm{D})$, as previously suggested in note 25 . 
We can now solve for the value of $Q$ that will yield the same condition for settlement as under the American rule given in inequality (18). This condition will occur when $Q=1$, which reveals that the rate of settlement will be identical under the British and American rules if the effect of adopting the British system is to double the combined legal expenses of the parties. If total litigation expenses more than double, the settlement rate will be higher under the British rule. If total expenses rise by less than 100 percent, the settlement rate will be higher under the American rule.

The ratio of total costs to damages $(C / D)$ under the current American rule in tort cases is roughly .5.34 This means that, unless the effect of the British rule causes this ratio to rise from .5 to 1 , the British rule still will reduce the likelihood of settlement as Posner and Shavell have claimed. While it is not preposterous that total costs would equal the amount in controversy under the British rule, given the higher stakes involved, it seems unlikely. Replacement of the American rule with the British rule increases the amount at stake for both the plaintiff and the defendant from $D$ to $1.5 D$. If the shift to the British rule raises the stakes of litigation by 50 percent, a good first approximation might be to assume that total litigation costs should increase by only 50 percent. ${ }^{35}$ If this increase occurred, then total costs under the British system would constitute 75 percent of the damages. In this event, the condition for settlement would be

(23) $P_{\mathrm{A}}-P_{\mathrm{B}}<\left(1-P_{\mathrm{A}}+P_{\mathrm{B}}\right) * .75$, which is equivalent to

(24) $P_{\mathrm{A}}-P_{\mathrm{B}}<.429$.

Inequality (24) reveals that the settlement range is smaller for the British rule than for the American rule but is larger than the Posner/Shavell analysis would suggest. ${ }^{36}$

The central insight of Hause's paper, that the British rule will lead to higher litigation costs, is quite important. But, while Hause's analysis is remarkably elegant and intellectually creative, his ultimate conclusion is flawed. The problem is that Hause and others appear to have overlooked the evidence on the size of legal costs relative to the amount in controversy. When Hause derived his condition for settlement under the British rule to account for increased litigation costs, he simply relied on his intuition in assessing whether the condition for settlement would be met under the British rule. Thus, contrary to my finding, Hause concludes that it is "intuitively plausible" that more settlements would occur under the British rule than under the American rule. He writes:

Plaintiff and defendant presumably get professional advice from their lawyers, so it is unlikely that $\left[P_{\mathrm{A}}-P_{\mathrm{B}}\right]$ is "large" relative to one. Yet it seems likely that the sum of the

34. See note 25 .

35. If the stakes for both parties rose by $50 \%$ to $1.5 \mathrm{D}$, one might expect litigation costs to rise from .5D to $.75 \mathrm{D}$, a $50 \%$ increase. The assumption of unitary elasticity of litigation expenses with respect to the possible damages may be unduly favorable to the Hause hypothesis. The law of diminishing returns suggests that the elasticity of these expenses would ultimately be less than one.

36. Compare inequality (24) to inequality (18) (the American Rule) and inequality (20) (the British rule without controlling for the higher litigation costs induced by this fee-shifting rule). 
legal expenditures may have a large percentage increase, given the difference in the probabilities. But this creates a larger range of mutual gain to the two parties from settlement, rather than going to trial and reducing their total wealth by [the added costs of trial]. This conclusion is the opposite of that reached by Shavell and Posner (in their formal analysis). ${ }^{37}$

This reasoning is puzzling. To sustain Hause's conclusion that more settlements will occur under the British rule than the American rule, $P_{\mathrm{A}}-P_{\mathrm{B}}$ must differ by more than $.5,{ }^{38}$ which would seem to conflict with his intuition that professional advice will make such large differences in probability assessments unlikely. ${ }^{39}$ On the other hand, if, as Hause seems to suggest, inter-party disagreements over the estimated likelihood of plaintiff success are always substantially less than .5-say, .33 or less-then all cases would settle under either the American rule or the British rule as inequalities (18), (20), and (24) attest.

Hause buttresses his intuition about the effect of the British rule on the settlement rate by proceeding through a simulation exercise in which he demonstrates that, in many different scenarios, the settlement range is larger under the British rule than under the American rule. Table 1 shows the ratios of total costs to damages that Hause assumes will occur under the British and American rules

Table $1^{40}$

Ratios of Total Litigation Costs/Damages in Hause's Simulations

\begin{tabular}{lcc}
\hline & American Rule & British Rule \\
\cline { 2 - 3 }$(1)$ & .147 & .486 \\
$(2)$ & .147 & .582 \\
$(3)$ & .147 & .963 \\
$(4)$ & .147 & .436 \\
$(5)$ & .147 & .501 \\
$(6)$ & .147 & .676 \\
$(7)$ & .147 & .378 \\
$(8)$ & .147 & .391 \\
$(9)$ & .147 & .249 \\
$(10)$ & .221 & .551 \\
$(11)$ & .221 & .465 \\
$(12)$ & .221 & .087 \\
\hline
\end{tabular}

In every case Hause's simulations for the American rule are based on estimates of the total costs of litigation that are dramatically below current

37. Hause, $18 \mathrm{~J}$ Legal Stud at 167 (cited in note 1).

38. See note 25 and inequality (18).

39. Part of the problem with Hause's supposition is that as the expenses of a case unfold they become sunk costs that can no longer serve as a "bribe" to settle. The process of securing a professional opinion about the merits of the case and conducting discovery means that more and more costs are being sunk, and the permissible range of disagreement is constantly narrowing. The inequality conditions employed throughout this literature are really assessments about the strength of the case prior to the expenditure of significant sums on legal advice and discovery.

40. Hause, $18 \mathrm{~J}$ Legal Stud at 170-71 (cited in note 1). 
estimates for tort litigation in the United States. ${ }^{41}$ Given these seriously understated figures for litigation costs under the American rule, it is not surprising that Hause's simulations show that the British rule leads to a greater likelihood of settlement. My more realistic figures demonstrate that, even correcting for the Hause effect of greater litigation costs under the British rule, the rate of settlement still will be somewhat lower than under the American rule. ${ }^{42}$

\section{The Hersch Extension}

Hersch recently provided an interesting extension to Hause's model of the settlement process. ${ }^{43}$ Hersch begins by recognizing Hause's contribution of modeling the rise in litigation expenses resulting from the shift to the British rule. He then draws upon an important insight from the industrial organization literature to adjust Hause's model to reflect the tendency of litigants to increase their expenditures in response to additional spending by an opponent. ${ }^{44}$

The essence of this insight suggests that, rather than simply trying to choose independently the best level of resources to devote to litigating a claim, each litigant may adjust his expenditures in response to the expenditures of the opposing side. As a result, litigation expenses will not increase as much under the British rule as Hause suggests, because increasing one's litigation expenditures is a less attractive strategy when these increases are in part offset by corresponding additional expenditures by the opposing party. ${ }^{45}$

Although Hersch finds the increase in total litigation expenses caused by the adoption of the British rule is smaller than that set forth by Hause, Hersch still concludes that on balance Hause was correct-the British rule will still stimulate more settlements than the American rule. Since I concluded that Hause's finding was incorrect and since Hersch's extension weakens Hause's argument, my conclusion applies a fortiori if one embraces Hersch's analysis. Moreover, Hersch bases his conclusion that the British rule stimulates settlements on simulations that use figures for the ratio of total costs to

41. Id. See also note 25 .

42. Compare inequality (18) to inequality (24). I again abstract away from the effects of risk aversion, which increases the likelihood of settlement under the British rule, and from Coasean bargaining, which tends to equalize settlement rates.

43. Hersch, $19 \mathrm{~J}$ Legal Stud at 235 (cited in note 11 ).

44. Id at 237-41. The insight, called a conjectural variation, was developed in oligopoly theory to reflect the fact that a price or quantity increase by one producer is likely to generate responses by competitors that will to some degree undermine the advantage of the initial producer's action.

45. Hiring a great attorney is somewhat like standing up at a foorball game to see an exciting play. If you alone stand up, you are better off. If the person in front of you also rises, you may not see any better, and you will both have the discomfort associated with standing. Similarly, if only one litigant can hire a great attorney, that party's probability of success will rise. If the opposing litigant hires a great attorney in response, the two attorneys may battle to a standstill, although they will charge their clients dearly for little relative gain. 
damages that are in many cases even more unrealistic than those presented by Hause. ${ }^{46}$

One conceptual issue that Hause and Hersch do not address bears mention. Both authors make the seemingly innocuous assumption that the probability of success at trial rises with one's own litigation expenditures. ${ }^{47}$ The problem is that the variable $P$ is the perceived probability of success at trial. The distinction is important because it is quite possible that expenditures on legal counsel will increase the actual probability of success at trial but diminish the perceived probability of success. Typically, investing in legal fees improves a party's chances of prevailing, and almost certainly guarantees a better outcome than would occur without such expenditures. However, as one's attorney works on a case, unfavorable information about the facts or law may be discovered. Consequently, the party's estimate of probable success at trial may actually decrease as legal work progresses.

Assume the expenditures generate information that will lower the party's perceived probability of prevailing at trial. Since perceptions govern the likelihood of settlement, Hause's assumption of the effect of expenditures on this perceived probability of success is problematic. On the other hand, when additional expenditures serve to diminish one's (presumably excessive) expectations of success, or to narrow the range of disagreement between the parties, ${ }^{48}$ the effect will be to increase the likelihood of settlement more under the British rule than under the American rule. ${ }^{49}$ Consequently, while there is

46. Hersch's predicted ratio of total costs to damages under the American rule ranges from $1 \%$ to $15 \%$. Hersch, $19 \mathrm{~J}$ Legal Stud at 239 (cited in note 11). These numbers are far below the true figure suggested in note 25 of approximately $50 \%$. Once again, it is not surprising that the incentive to settle under the American rule is so low in the Hersch simulations, given the unrealistically low magnitude of the hypothesized litigation costs. 11).

47. Hause, $18 \mathrm{~J}$ Legal Stud at 165 (cited in note 1); Hersch, $19 \mathrm{~J}$ Legal Stud at 240 (cited in note

48. If additional expenditures by both parties enable them to predict more accurately the likelihood of success by the plaintiff, then this convergence in their estimates will make settlement more likely.

Professor Anthony D'Amato has clarified the effect of lawyers' uncertainty on the likelihood of settlement. Uncertainty in estimates about the likelihood of success can take at least two forms: (1) it can lead to divergences in the point estimates of the likelihood of success at trial, and (2) it can generate doubts about the accuracy of one's point estimate of the likelihood of success at trial. To illustrate these two effects, consider the case in which there is no information at all about how a decisionmaker will rule in a given case. It is then equally likely that the plaintiff's probablity of success is zero or one, or anything in between. Given this lack of information, the best point estimate of the likelihood of success is .5 , but there is obviously a high degree of uncertainty about the accuracy of this point estimate. Conversely, when we flip a coin, we have a great deal of confidence in out point estimate that the probablity of a head is .5. These two effects have conflicting impacts on the likelihood of settlement: diverging point estimates will narrow the settlement range, which is generally thought to reduce the likelihood of settlement, while the imprecision of the point estimate is likely to increase the rate of settlement. Such imprecision will increase the risk in going to trial, thereby creating an incentive for settlement for risk averse parties. Furthermore, it may also increase the costs of litigation: parties will expend more effort trying to determine what the law is and will likely need to have a more comprehensive and costly trial strategy than would be necessary if the law were known with great precision. Anthony D'Amato, Legal Uncertainty, 71 Cal L Rev 1, $15-18$ (1983).

49. Pessimism by either party promotes settlement, but the British rule magnifies this effect because it not only reduces the expectations of damages but also increases the size of the bribe by increasing expected litigation costs. The latter effect does not operate under the American rule. 
a conceptual difficulty in this part of Hause's analysis, the correction would operate in favor of his thesis that settlements are more likely under the British rule.

\section{An Overall Assessment}

Where does this leave us? As the above discussion illustrates, the array of probabilities of $P_{\mathrm{A}}$ and $P_{\mathrm{B}}$ that will lead to settlement is greatest for the American rule, smallest under the Posner/Shavell analysis of the British rule, and almost halfway in between for the British rule with the Hause correction for higher litigation fees. This last condition, inequality (24), would be slightly less favorable to settlement if the Hersch effect is considered. Therefore, if one synthesizes the preceding discussion into a rough rule of thumb, it might be that cases in which $P_{\mathrm{A}}-P_{\mathrm{B}}$ is less than .5 will settle under the American rule, and cases in which $P_{\mathrm{A}}-P_{\mathrm{B}}$ is less than .4 will settle under the British rule. ${ }^{50}$ This rule of thumb suggests that the settlement range would decrease by about 20 percent with the adoption of the British rule, although this does not imply that the settlement rate ${ }^{51}$ would fall by that percentage. ${ }^{52}$

When one introduces the concept of risk aversion, the rather modest depressing effect of the British rule on the settlement rate may be entirely offset by an increase in the parties' aversion to going to trial given the increase in the sanctions associated with an adverse result. As Judge Posner observed in his first examination of this issue in 1973, "[ $t$ ]he greater variance of returns under the English rule makes the expected value of litigation less for riskaverse litigants, which will encourage settlements if risk aversion is more common than risk preference." 53 When one adds this factor into the analysis, my best guess is that the effect of risk aversion in inducing settlement at least offsets the shrinkage of the settlement range resulting from the adoption of the British rule. Thus, in 1973 Posner probably reached the correct conclusion about the effect of the British rule on the settlement rate. Later, Posner and Shavell importantly analyzed the shrinkage in the settlement range but exaggerated its size and probably over-dramatized its ultimate effect. Hause and Hersch provided important contributions concerning the effect on litigation costs of the change in rules, but wildly overestimated the impact of this factor. In the end, adopting the British rule would probably have little effect or provide only a mild stimulus to the rate of settlement.

50. If one were to relax the previous assumption that $D$ was known by the parties, then an additional level of uncertainty would be introduced into these conditions for settlement. But as long as the parties' estimates of $D$ were unbiased, the conditions stated in the text will be true on average. Conversely, if defendants tend to have upwardly biased estimates of $D$ or plaintiffs have downwardly biased estimates of $D$, then the likelihood of settlement will increase.

51. The settlement rate describes the actual rate at which parties settle, while the settlement range describes the diffferences between the net amount that the plaintiff expects to receive and the defendant expects to pay if they proceed to trial.

52. If, for example, Hause's intuition that relatively few cases would have sizable disagreements in the expected probability of plaintiff's success, then few cases would fall in the range of $.4<P_{A}-$ $P_{\mathrm{B}}<.5$, in which case the decline in the settlement rate would be small.

53. Posner, $2 \mathrm{~J}$ Legal Stud at 428 (cited in note 1). 
Thus, the Coasean prediction, if not its precise mode of implementation, may prevail.

\section{IV}

\section{The Settlement Question in a Contingency Fee Context}

Much tort litigation is pursued under a contingency fee arrangement, yet the literature on fee-shifting has analyzed the decision to settle or proceed to trial without reference to this institutional feature. ${ }^{54}$ Under a contingency fee arrangement, the likelihood is small that parties in tort litigation would want to engage in Coasean contracting for a British rule. The contingency fee is the plaintiff's mechanism of escaping risk, while the British rule compounds risk. Therefore, a number of interesting insights are revealed by explicitly considering the effect of contingency fees on the likelihood of settlement, while holding in abeyance the prospect of Coasean rule shifts.

\section{A. The American Rule}

The dominant feature of tort litigation in the United States is that plaintiffs typically contract with attorneys who will handle their cases in return for onethird of the amount collected from the defendant through judgment at trial or settlement. This arrangement means that if the litigation yields an immense award, the lawyer may achieve a return disproportionate to the amount of time and effort invested in the case, but if the case yields no award or settlement, the attorney will receive nothing and the litigation will have cost the plaintiff nothing. In this situation the expected benefit to the plaintiff of proceeding to trial is

(25) $E B_{\mathrm{A}}=P_{\mathrm{A}}^{*}(.67 D)$.

The expected cost to the defendant of proceeding to trial again is

(26) $E C_{\mathrm{B}}=P_{\mathrm{B}} D+C_{\mathrm{B}}$.

So far, we have adhered to the customary assumption that settlement will occur if the expected benefit to the plaintiff of going to trial is less than the expected cost to the defendant of going to trial. Continued adherence to this assumption suggests that a settlement would occur if

(27) $P_{\mathrm{A}}^{*}(.67 \mathrm{D})<P_{\mathrm{B}} D+C_{\mathrm{B}}$.

However, this rule is not correct for settlement under a contingency fee. For simplicity, assume that $P_{\mathrm{A}}$ equals $P_{\mathrm{B}}$ equals .5; the damage award $D$ equals $\$ 1000$; and the defendant's trial costs $C_{\mathrm{B}}$ equals $\$ 150$. In this case, inequality (27) clearly holds since

(28) $.5 *(.67 * 1000)<.5 * 1000+150$, and

54. Some of the major references examining issues of settlement in a contingency fee context are F. B. MacKinnon, Contingent Fees for Legal Services 74-77, 195-200 (Aldine, 1964); Murray L. Schwartz \& Daniel B. Mitchell, An Economic Analysis of the Contingency Fee in Personal Injury Litigation, 22 Stan L Rev 1125 (1970); Kevin M. Clermont \& John D. Currivan, Improving on the Contingent Fee, 63 Cornell L Rev 529 (1978); and Geoffrey P. Miller, Some Agency Problems in Settlement, 16 J Legal Stud 189 (1987). 
(29) $333<650$.

But inequality (29) incorrectly suggests that both parties would be better off with any settlement greater than $\$ 333$ and less than $\$ 650$. The expected value to the plaintiff of going to trial is $\$ 333$, yet if the case settles for this amount, the plaintiff walks away with only $\$ 222$, and his lawyer keeps the rest. Similarly, if the parties settle the case for $\$ 450$, the 3 efendant is clearly better off than if the action proceeds to trial, but the plaintiff is not better off. Because of the contingency fee arrangement with his lawyer, the plaintiff receives only $\$ 300$ of the $\$ 450$ settlement. ${ }^{55}$ Unless the settlement figure is at least $\$ 500$, the plaintiff would be better off pushing the case to trial. ${ }^{56}$

Accordingly, the true bargaining range, as long as the lawyer follows his professional responsibility of promoting the best interest of the client, will be narrower than inequality (27) indicates. The appropriate condition for settlement is therefore given by

(30) $P_{\mathrm{A}} D<P_{\mathrm{B}} D+C_{\mathrm{B}}$, which can be re-written as

(31) $P_{\mathrm{A}}-P_{\mathrm{B}}<C_{\mathrm{B}} / D$.

Previously we had found that, under the American rule without a contingency fee, settlement would occur when the difference in the parties' estimates of the probabilities of plaintiff's success were less than the ratio of all trial costs divided by the possible judgment. ${ }^{57}$ Inequality (31) shows that the introduction of the contingency fee narrows this bargaining range, and the likelihood of settlement declines in accordance with the customary assumptions of the literature. A plausible figure for $C_{\mathrm{B}} / D$ might be roughly $.167 .{ }^{58}$ In this event the condition for settlement of a contingency fee case under the American rule would be

(32) $P_{\mathrm{A}}-P_{\mathrm{B}}<.167$.

As we have stressed throughout, the desire to avoid litigation expenses provides a powerful incentive to settle cases. The contingency fee dampens this incentive because the plaintiff pays one-third of the amount collected from the defendant to his attorney regardless of whether the case is tried or settled. Therefore, the size of the "bribe" to settle is smaller with a contingency fee. ${ }^{59}$

55. The most common contingency fee has been one-third of all proceeds, but apparently this percentage has been creeping upwards towards $50 \%$ in some cases. Furthermore, specialized contingency fee contracts occasionally are negotiated to provide for a smaller percentage if the case is settled or the case generates an award above a certain level.

56. Note the obvious conflict of interest that emerges between the plaintiff and his attorney in this situation. If the client accepts the $\$ 450$ settlement, he is worse off than if he pushes the case to trial, but his lawyer may be significantly better off. The settlement brings the lawyer a fee of $\$ 150$, while the expected fee from trial is only $.5 *(.333 * \$ 1000)=\$ 167$. The lawyer's expected marginal compensation for trying the case is only $\$ 17$. The problem of conflicts of interest will be discussed further in the following section.

57. See inequality (10).

58. If total litigation costs $C_{\mathrm{A}}+C_{\mathrm{B}}=.5 \mathrm{D}$ and plaintiff's cost $C_{\mathrm{A}}=.333 \mathrm{D}$, then defendant's cost $C_{\mathrm{B}}=.167 \mathrm{D}$.

59. This discussion abstracts from some real world complexities. Typically, certain litigation expenses will be incurred if the case goes to trial that would be avoided through settlement. Plaintiffs' attorneys often will capture these expenses out of any judgment for the plaintiff, which will 


\section{B. Conflicts of Interest between Plaintiffs and Their Lawyers}

Thus far, the discussion of contingency fees implicitly has assumed that the plaintiff will insist on trial whenever it is to the plaintiff's advantage to do so vis-á-vis the initial contingency contract. This assumption led us, in one sense, to disregard the plaintiff's legal costs in the event of trial, because these costs do not provide the usual incentive to settle given the nature of the contingency fee. The reason is that the plaintiff will lose one-third of the award from the defendant regardless of whether it comes via trial or settlement. When the plaintiff pays his attorney on an hourly basis, a $\$ 500$ settlement offer is more valuable than a $\$ 500$ judgment obtained after undergoing the expense of a trial. In the contingency fee context, these options, are equally attractive to the plaintiff. 60

But while the plaintiff is indifferent between these two options since he will end up with two-thirds of $\$ 500$ in either case, his lawyer clearly is not. Since the lawyer secures one-third of $\$ 500$ in both cases, he clearly prefers the settlement since it saves him the burden of trial. As noted above, this difference can lead to a situation in which the plaintiff will benefit from going to trial by an amount that is less than the cost to his attorney from doing so. In this event, a Pareto optimal deal between the plaintiff and his lawyer exists in which the plaintiff would agree to accept the proposed settlement offer in exchange for paying his lawyer less than the customary one-third contingency fee. This renegotiation between the plaintiff and his attorney would make both parties better off. If such renegotiation could be achieved quickly, then the above analysis would incorrectly understate the likelihood of settlement.

This analysis raises the interesting question of what the ethical lawyer would do when this circumstance, which is actually fairly common in the contingency fee arena, arises. What frequently happens in practice is that the lawyer will try to convince his client that the settlement is a good deal for the client, even though the expected value to the plaintiff of going to trial is greater than the value of the settlement. This action appears to be the prototype of unethical behavior since it involves the lawyer using his skills to mislead his client to the advantage of the lawyer and the detriment of the client. One might contend that lawyers should always take such cases to trial given the fact that, under the incentives arrayed by the contingency fee, it would be in the best interest of the client. Allowing, or indeed requiring, the plaintiff's lawyer to negotiate a Pareto-improving settlement and reduction of

\footnotetext{
increase the incentive to settle beyond the level suggested in the text. For example, if the contingency fee posits that expert witness fees are to be paid by the successful plaintiff, then this amount will increase the size of the bribe to settle. Lawyers frequently will apply their one-third percentage to the total judgment and then subtract the expert witness fees from the two-thirds going to the client. This method is obviously less advantageous for clients than if the one-third contingency fee is applied to the net judgment (award minus expert witness fees), but it will increase the incentive to settle.

60. I abstract from the issue of the time value of money, which would make the future judgment less attractive than the immediate settlement.
} 
the attorney's one-third fee is a possibility, but such renegotiations are not without potential drawbacks.

The benefit of renegotiation is that the attorney is being candid with the client and can attempt to improve the client's position above either standard settlement or trial. Again, if the renegotiation can be achieved at relatively low cost, everyone wins, as the expense and burden of trial are avoided. The problem is that anything other than a prophylactic rule requiring the attorney to take the case to trial raises the possibility that the attorney and the client will be in conflict at a time when the client is very dependent on the attorney for loyal advocacy. A conceptually satisfactory solution would be to leave all of the gains from renegotiation with the plaintiff. Recall the above example where both parties agree that the plaintiff's probability of success is .5 , and $D$ equals $\$ 1000$. Here, the lawyer's expected fee from trial is $\$ 167$, leaving the client with $\$ 333$. A $\$ 450$ settlement offer yields only $\$ 300$ for the plaintiff, so the risk-neutral plaintiff would clearly prefer trial to settlement. But the plaintiff's lawyer would probably make the opposite choice: by settling the case he makes $\$ 150$ without incurring the expense and bother of trial. Requiring the lawyer to confer upon the client $\$ 333$ of the $\$ 450$ settlement offer solves the lawyer's conflict of interest but leaves only $\$ 117$ as the attorney's fee, a reduction in his percentage from 33 percent to 26 percent. ${ }^{61}$ The costs of monitoring a requirement that attorneys renegotiate their fees to protect the interests of their clients may well make such a system too costly to implement.

\section{The British Rule Super-Imposed on the American Contingency Fee}

Assume that the British rule were adopted in the United States for tort actions, or, perhaps more likely, the contingency fee were adopted in England. ${ }^{62}$ The effect of such a change on the rate of settlement would depend on the precise fee arrangements negotiated between plaintiffs and their attorneys. The primary questions whose resolution would define the nature of the contingency fee under a fee-shifting rule are what percentage of the total recovery will the plaintiff's attorney receive as compensation, will this percentage be applied to the award plus the attorney's fee or just the award itself, and who will pay the defendant's attorney's fees in the event that the plaintiff loses?

1. The Plaintiff's Lawyer Pays Fees in the Event of Loss. Let us begin with the assumption that the fee arrangement would be structured as follows: (1) if the plaintiff wins, the jury award of $D$ would go directly to the plaintiff, and the defendant would pay plaintiff's attorney's fee $\left(C_{\mathrm{A}}\right)$ of .33D (33 percent of $D$ ); and (2) if the defendant wins, the plaintiff's lawyer would pay the defendant's

61. $\$ 117 / \$ 450=26 \%$.

62. In 1989, Margaret Thatcher proposed that the contingency fee be adopted for tort cases in England. Richard A. Melcher, Thatcher's New Revolution, Business Week 42 (May 1, 1989). 
costs $\left(C_{\mathrm{B}}\right) .{ }^{63}$ In this event, the case would settle as long as the following condition holds:

(33) $1.5 * P_{\mathrm{A}} D<P_{\mathrm{B}} D+P_{\mathrm{B}}\left(C_{\mathrm{A}}+C_{\mathrm{B}}\right)$, ${ }^{64}$ which, given the assumption that $\left(\mathrm{C}_{\mathrm{A}}+\mathrm{C}_{\mathrm{B}}\right) / D=.5$ is equivalent to

(34) $P_{\mathrm{A}}-P_{\mathrm{B}}<0$, which in turn reduces to

(35) $P_{\mathrm{A}}<P_{\mathrm{B}}$.

A comparison of inequalities (32) and (34) indicates once again that fewer settlements will occur under a British rule.

Figure 1 depicts the range of probabilities of $P_{\mathrm{A}}$ and $P_{\mathrm{B}}$ in which a settlement range exists for the American and British rules with and without contingency fees. Any combination of plaintiff and defendant assessments of the probability of plaintiff's success that will lead to settlement will lie either on or below the relevant line. The line emerging from the origin, which corresponds to inequality (35), indicates that any combination of probabilities below and to the right of this line will lead to settlements of contingency fee cases under the British rule. The parallel line above it, which emanates from the vertical axis at .17 (probability of 17 percent) and corresponds to inequality (32), reveals the various combinations that lead to settlements under contingency fees under the American rule. The line emanating from the vertical axis at .33 (probability of 33 percent), which corresponds to inequality (17), pertains to the British rule without contingency fees. The highest line, which corresponds to inequality (15) and emanates from the vertical axis at .5 (probability of 50 percent), pertains to the American rule without contingency fees.

63. Plaintiff's lawyer would be unlikely to accept the same percentage compensation as under current contingency fee arrangements, because he would bear the additional burden of paying defendant's lawyers in the event of a loss. Therefore, a more realistic estimate would likely involve a $40 \%$ contingency fee. As the percentage of the plaintiff's attorney's fee increases, the range of probabilities that will support settlements will shrink. For example, at $40 \%$, this range will be given by the equation $P_{\mathrm{A}}<.94 * P_{\mathrm{B}}$, which is smaller than the range associated with inequality (35).

One possible fee agreement provides that the plaintiff's attorney would aggregate the damage award and the attorney's fee award, then take one-third of this amount. If the fee award equalled one-third of the damage award, this fee would leave the plaintiff's attorney with 4/9 of the damage award, which is roughly $44 \%$. This approach was essentially the contingency fee agreement in Marek $v$ Chesny, 473 US 1 (1985), where the lawyer was to receive $45 \%$ of all proceeds of any kind. See Miller, $16 \mathrm{~J}$ Legal Stud at $204 \mathrm{n} 50$ (cited in note 54). Marek held that a prevailing civil rights litigant otherwise entitled to attorney's fees is barred by Rule 68 of the Federal Rules of Civil Procedure from recovering any fees for work performed after rejecting a settlement offer if his recovery is less than the amount proffered in settlement. $473 \mathrm{US}$ at 11.

64. As we saw in comparing inequalities (27) and (30) above, the plaintiff's lowest acceptable settlement offer is given by multiplying the plaintiff's expected trial outcome-here $P_{A} D-$ by 1.5 . It might seem, however, that the multiplier of 1.5 is not needed here since we are assuming that the plaintiff is shielded from a concern with the legal fees at trial: either the defendant will pay all the legal fees (if plaintiff wins) or the plaintiff's lawyer will pay all the legal fees (if plaintiff loses). But note that if the expected outcome at trial is $P_{A}^{*} D$, the plaintiff would not be willing to settle for this amount; if he did so, the plaintiff would not get the benefit of fee-shifting, and the plaintiff would still have to pay his lawyer one-third of $P_{A}^{*} D$. Going to trial yields an expected benefit of $P_{A}^{*} D$ for the plaintiff, while settling for this same amount provides only $.67^{*} P_{*}^{*} D$. Thus, to determine the minimum amount that the plaintiff would be willing to accept in settlement, we must multiply the expected trial outcome by 1.5 . 
Figure 1

\section{The Range of Settlement Probabilities}

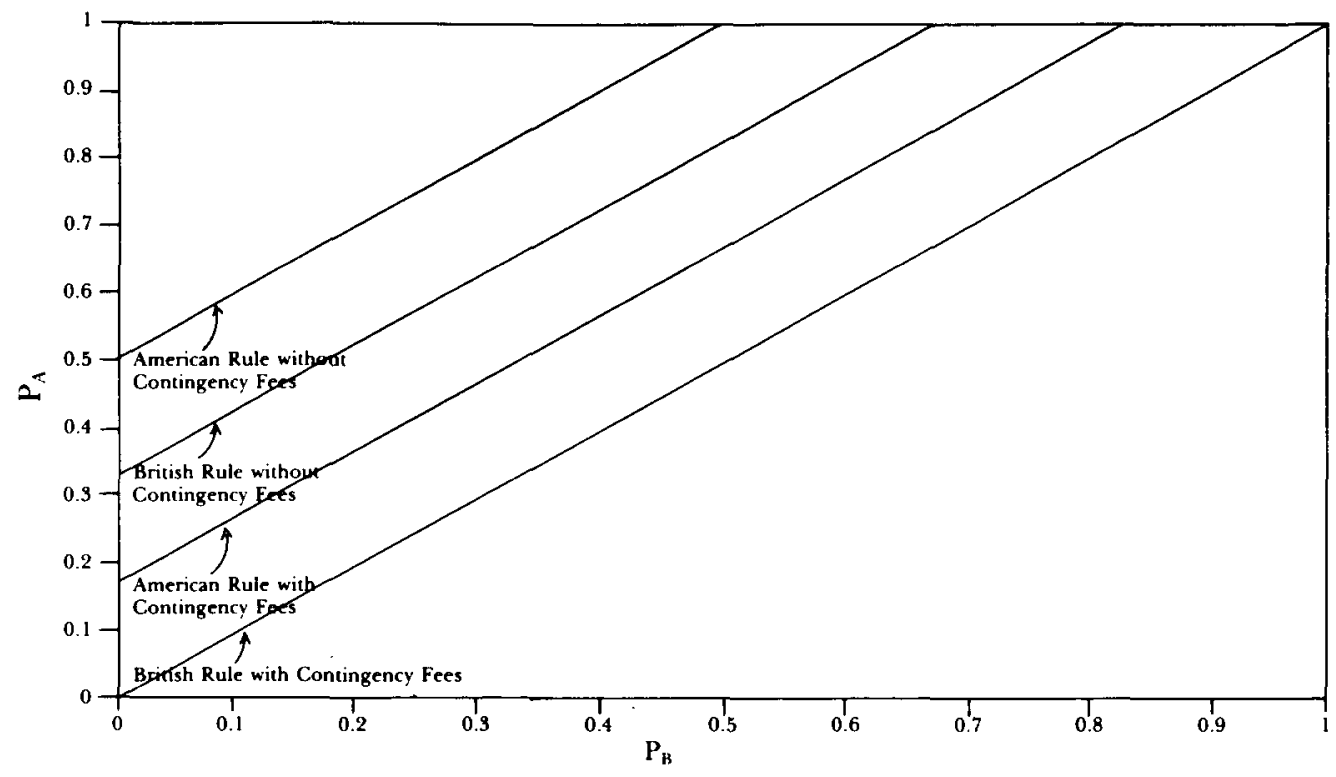

Note that the range of probabilities that can support Pareto-improving settlements is always greater with the American rule than with the British rule, whether or not the litigation is conducted with a contingency fee. But, as Figure 1 clearly shows, the effect of a shift from the American rule to the British rule is modest in comparison to the effect of the shift from a nocontingency fee situation to a contingency fee. Since the conventional analysis of the American rule suggests that whenever $P_{\mathrm{A}}-P_{\mathrm{B}}<.5$ the case will settle, substantial disagreements about the likelihood of success are needed before the case will proceed to trial. With a contingency fee, however, the range of potential disagreement is sharply curtailed, with the condition for settlement being $P_{\mathrm{A}}-P_{\mathrm{B}}<.167$. In other words, if the plaintiff thinks his probability of success is .6 while the defendant's estimate is only .4 , the case will not settle under a contingency fee agreement because no settlement range exists.

2. The Losing Plaintiff Pays Defendant's Fees. Thus far, our discussion of the contingency fee scenario under the British rule has assumed that the plaintiff's lawyer will pay the defendant's costs if the defendant prevails at trial. It is possible, though, that the introduction of the British rule would alter the nature of contingency fee contracts so that losing plaintiffs would be responsible for the fees of prevailing defendants. ${ }^{65}$ In this case, the condition for settlement would be given by the following inequality:

65. I now return to the assumption that the plaintiff's attorney will receive one-third of the damage award or settlement amount since, from the attorney's perspective, this situation is identical to existing contingency fee contracts under the American rule. 
(36) $1.5^{*}\left[P_{\mathrm{A}} D-\left(1-P_{\mathrm{A}}\right)^{*} C_{\mathrm{B}}\right]<P_{\mathrm{B}} D+P_{\mathrm{B}}\left(C_{\mathrm{A}}+C_{\mathrm{B}}\right)$, which is equivalent to

(37) $1.5^{*} P_{\mathrm{A}}-P_{\mathrm{B}}<1.5^{*}\left(1-P_{\mathrm{A}}\right)^{*} C_{\mathrm{B}} / D+P_{\mathrm{B}}\left(C_{\mathrm{A}}+C_{\mathrm{B}}\right) / D$.

If we retain our previous assumptions, ${ }^{66}$ then inequality (33) becomes

(38) $P_{\mathrm{A}}<.143+.857^{*} P_{\mathrm{B}}$.

We can now compare the effect of this modification of our analysis of the British rule with contingency fees to our previous assessments of the conditions for settlement under contingency fees. Figure 2 imposes the graph of this modification on top of the previous two lines representing the range of settlement probabilities with a contingency fee as depicted in Figure 1. The new line, which emanates from .143 (probability of 14 percent) on the vertical axis, is only modestly below the line representing the American rule with a contingency fee for low values of $P_{\mathrm{A}}$, but its lower slope causes a constant divergence as $P_{\mathrm{A}}$ rises. In other words, when losing plaintiffs are themselves responsible for defendants' fees, the British rule will reduce the bargaining range for plaintiffs pessimistic about their chances of success only slightly below the bargaining range under the American rule. But the impact of the British rule in diminishing the likelihood of settlement grows as the plaintiff becomes more optimistic that the burden of defendant's costs will be avoided.

Figure 2

\section{The Range of Settlement Probabilities}

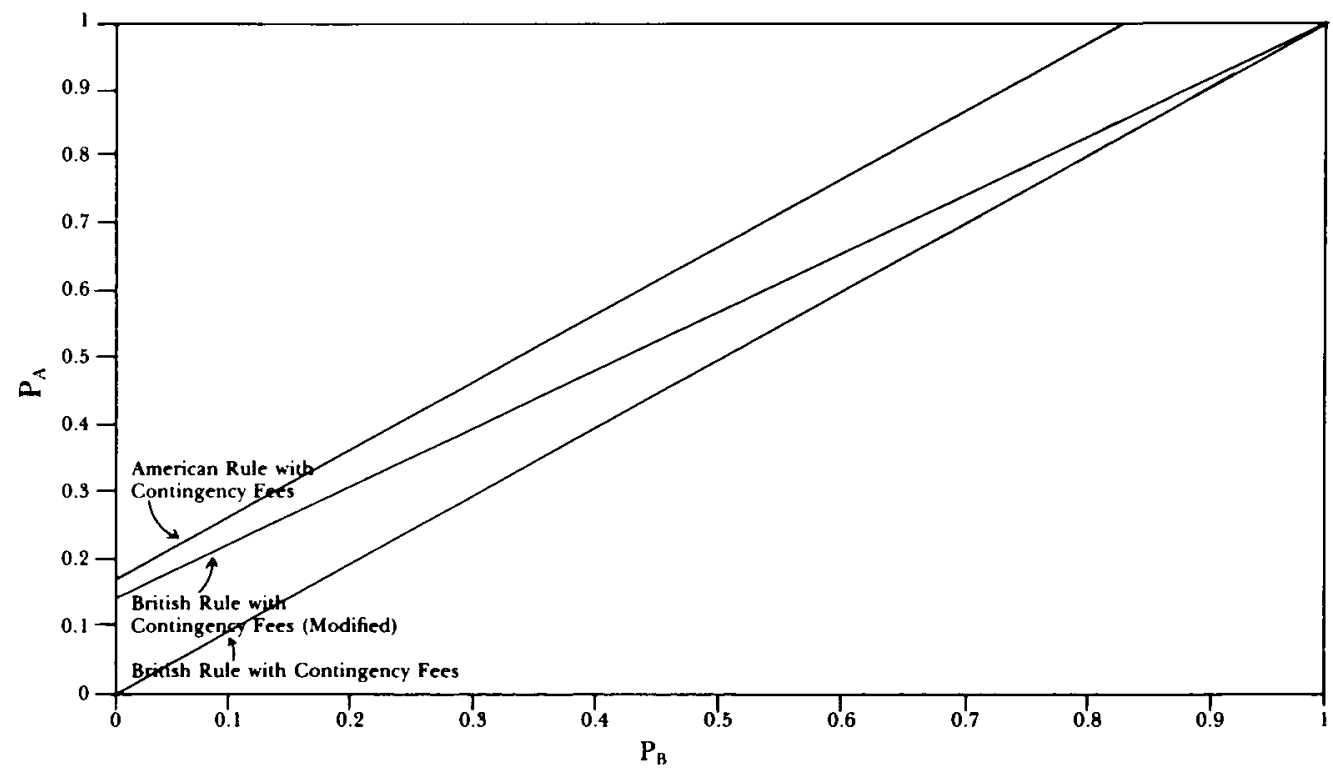

3. Will Fee Shifting Affect the Size of Jury Awards? So far the discussion of the effect of the British rule has not considered the possibility that trial outcomes might be affected by the adoption of a fee-shifting regime. Specifically, if

66. These assumptions were $\left(C_{\mathrm{A}}+C_{\mathrm{B}}\right) / D=.5$ and $C_{\mathrm{B}} / D=.167$. 
juries know that a verdict of $\$ 300,000$ will yield a benefit of $\$ 200,000$ to the plaintiff, they may act differently than if they realize that a verdict of $\$ 300,000$ will be retained in full by the plaintiff. If a juror really believes that a victim in a jurisdiction governed by the American rule deserves $\$ 300,000$, the jury would have to jack up the award by 50 percent to ensure a recovery by the plaintiff of this amount after a contingency fee was paid. Accordingly, one might expect that the adoption of the British rule would lead to a decline in the level of damages $D$ as there would be no need to increase awards.

Of course, judges could police any attempt to increase awards by juries operating under the American rule, but such monitoring is unlikely to be entirely effective. On the other hand, not all jurors will be aware of the contingency fee mechanism or be inclined to compensate deserving plaintiffs more because of it. To explore the tendency to award lower damages under the British rule, we begin with the assumptions that jury awards drop by roughly 10 percent after the adoption of the British rule and that both parties are aware of this phenomenon. ${ }^{67}$ In this event, the condition for settlement becomes

(39) $1.5 * P_{\mathrm{A}}(.9 D)<P_{\mathrm{B}}(.9 D)+P_{\mathrm{B}}\left(C_{\mathrm{A}}+C_{\mathrm{B}}\right)$.

If we make the reasonable assumption that, with the lower expected stakes, the parties will reduce their litigation expenses so that the ratio of total costs to potential award equals .5 , then the condition for settlement becomes ${ }^{68}$

(40) $1.5^{*} P_{\mathrm{A}}<1.5^{*} P_{\mathrm{B}}$, which in turn reduces to:

(41) $P_{\mathrm{A}}<P_{\mathrm{B}}$. Note that condition (41) is identical to condition (35), which governed the case of the British rule with contingency fees (assuming plaintiff's attorney would pay defendant's costs in event of loss) without any jury offset. In general, then, as long as costs adjust to remain a constant percentage of damages, offsetting adjustments to jury verdicts prompted by the adoption of a British rule will have no effect on the rate of settlement as compared to the rate of settlement prevailing in the absence of these adjustments.

\section{Re-Examining the Concept of the Setrlement Range}

The opinion is commonly expressed that cases should always settle because the different expectations of the probability of plaintiff's success will be narrowed sharply as the parties secure professional advice. ${ }^{69}$ In this view, it seems that all cases under the American rule should settle since the parties

67. If all jurors were inclined to compensate plaintiffs more under the American rule and judges were wholly ineffective in restricting this practice, then the adoption of the British rule would lead to a $33 \%$ drop in average jury awards.

68. The assumption that the ratio of total costs to potential award remains at .5 implies that $\left(D_{A}\right.$ $\left.+C_{\mathrm{B}}\right) / .9 D=.5$, since $.9 D$ is the potential award given the $10 \%$ reduction. Consequently, dividing inequality (39) by $.9 D$ yields the following inequality: $1.5 P_{:}<P_{\mathrm{B}}+.5 P_{\mathrm{B}}$.

69. See, for example, the quote by Hause presented in the text accompanying note 37 . 
will virtually always be within the previously specified .5 settlement range if they are counseled by experienced attorneys.

\section{A. The Conflicting Effects of Pre-Trial Expenditures}

This sentiment overlooks the fact that attorneys do not have an opinion about the probability of success of a client's case from the minute the client walks in the door. Research, fact-finding, and lengthy discovery are all prerequisites to the formulation of an opinion. Surely, as this process unfolds, there will be a narrowing in the range of disagreement between the two parties, but at the same time, there will be a continuing diminution in the legal fees that settlement will avoid. The figures that have been presented as the conditions for settlement apply only at the start of litigation, before substantial portions of the total costs of litigation-the bribe to settle-have been spent. Thus, the narrowing of uncertainty will be an inducement to settle only if it can be achieved cheaply enough. If discovery is both incredibly expensive and revealing, the left-hand side of the condition for settlement may not be shrinking any faster than the right-hand side:

(42) $P_{\mathrm{A}}-P_{\mathrm{B}}<$ (total remaining costs/damages).

It should not be surprising that a lawyer's assessment of the chance of success, based only on the reports of his client, are sufficiently inaccurate and optimistic to explain the sizable number of cases that proceed through discovery. The parties only move toward settlement if the narrowing uncertainty from the legal expenditure is greater than the simultaneously diminishing range of settlement.

\section{B. Settlement in Mass Tort Litigation}

These factors explain one common pattern in mass tort litigation. Frequently, when the crisis erupts, whether the problem is asbestos, DES, or some other product, there is a great deal of uncertainty about the extent of liability and the size of likely recoveries. Therefore, even though the expense of litigation is high, there is little movement toward settlement in the vast preponderance of the cases. Typically, plaintiffs and defendants can be organized into different categories based on certain factual or legal issues. As the courts process cases that fall into certain categories, such as those concerned with asbestos-related injuries, other litigants from within those categories are able to refine their estimates of the probability of success and to narrow their range of disagreement without expending any of their own resources. Consequently, these remaining litigants are able to narrow the range of disagreement between plaintiff and defendant without simultaneously diminishing the size of the bribe to settle.

Since the size of the bribe to settle, expressed as some percentage of the total amount in controversy, is virtually identical for litigants within the same categories, and since the available information from the judgments in the pioneering cases are quickly evaluated by interested attorneys, at some point the uncertainty of a given class of litigants is narrowed to such an extent that 
the percentage difference in expectations of plaintiff's success drops below the percentage cost figure. At this point, since the cases in a given class are generally comparable, a rapid process of settlement occurs in which hundreds of cases can be resolved quickly. Indeed, this pattern, which closely conforms to what one would expect given the theoretical understanding of the settlement process, is a good description of mass tort litigation.

\section{The Size of the Settlement Range: Conflicting Effects}

Thus far, I have followed the convention of the current literature, which assumes that, if a range exists in which a Pareto-improving settlement can be negotiated, the case will settle. The focus, therefore, has been on whether such a settlement range exists. The number of cases that fall into this category is greater with the American rule and without contingency fees than with the British rule and with contingency fees. Yet, the existence of settlement ranges in two cases may not imply, as the current literature has assumed, that the two cases are equally likely to settle. For example, consider the case in which $D$ equals $\$ 1000, P_{\mathrm{A}}$ equals .7 and $P_{\mathrm{B}}$ equals .4 , and $C_{\mathrm{A}}$ equals $C_{\mathrm{B}}$ equals $\$ 300$. Under the American rule, both parties would be better off with a settlement somewhere in the range between $\$ 400$ and $\$ 700$ than with trial. Now imagine that the British rule applied in such a case. The plaintiff would expect to receive $\$ 520^{70}$ from trial while the defendant would expect to pay $\$ 640 . .^{71}$ Are these two cases equally likely to settle, as the literature has consistently assumed? ${ }^{72}$

It seems that two competing factors operate in cases that have settlement ranges and therefore at least satisfy the necessary condition for settlement. First, the greater the settlement range, the greater the likelihood that the parties will realize that settlement is a viable option. This realization is the recognition effect, and it suggests that, for the example above, the case has a settlement advantage under the American rule because the settlement range is wider and therefore more likely to be perceived by the parties. This effect is important because, strategically, a litigant wants to convince his opponent that his threat value is far higher than it actually is in order to capture more of the surplus resulting from their cooperation. The art of negotiation is to push the other side as far as possible without causing impasse or breakdown. This attitude may cause parties to fail to realize that Pareto improvements are available options. Second, the greater the settlement range, the greater the benefits from hard bargaining. Since more is available to be captured through negotiations, the parties will have an incentive to expend resources and effort in trying to capture it. But hard bargaining can increase the chance that the

70. $\$ 700-\$ 180=\$ 520$. See inequality (11).

71. $\$ 400+\$ 240=\$ 640$. See inequality (12).

72. To take an even more pointed example, compare the case in which the settlement range is $\$ 400$ to $\$ 700$ with the case in which the settlement range is restricted to $\$ 550$. Which one is more likely to settle? 
parties will bargain to impasse. This stalemate effect will therefore cut in the opposite direction from the recognition effect. ${ }^{73}$

If the stalemate effect is empirically significant, then the analysis of the differing legal rules becomes quite difficult, since for some values of $P_{\mathrm{A}}$ and $P_{\mathrm{B}}$ the settlement range is larger under the American rule than under the British rule, and for other values of these probabilities the reverse is true. For example, Figures 3-5 show the settlement ranges for differing values of $P_{\mathrm{A}}$ and $P_{\mathrm{B}}$ for the case in which $D$ equals $\$ 1000$ and total litigation costs equal $\$ 500$. The settlement range associated with any given pair of estimates of $P_{\mathrm{A}}$ and $P_{\mathrm{B}}$ will simply be given by the difference between the defendant's expected loss at trial and the plaintiff's expected gain from going to trial. Figure 4, which is prepared for all values of $P_{\mathrm{A}}$ when $P_{\mathrm{B}}$ equals .5 , confirms what we discussed above: the settlement range is positive for a greater range of probabilities under the American rule. This assertion is shown by the fact that the settlement range is always at least zero for all values of $P_{\mathrm{A}}$ given that $P_{\mathrm{B}}$ equals .5 for the American rule, while the settlement range turns negative-therefore barring the possibility of settlement-for high probabilities of $P_{\mathrm{A}}$ under the British rule.

But we are now interested in more than simply whether the settlement range is positive, which has been the focus of this paper heretofore. We are now interested in whether settlement probabilities will be influenced by the size of the settlement range. Note that the lines representing the settlement ranges for the British and American rules always cross where $P_{\mathrm{A}}$ equals $P_{\mathrm{B}}$. To the right of this point of intersection, where $P_{\mathrm{A}}$ is greater than $P_{\mathrm{B}}$, the bargaining range will be smaller for the British rule. In this region, the British rule would be more favorable to settlement if the stalemate effect dominates the recognition effect, and less likely otherwise. Conversely, for values of $P_{\mathrm{A}}$ to the left of the point of intersection, where $P_{\mathrm{A}}$ is smaller than $P_{\mathrm{B}}$, the recognition effect would favor the British rule as a means of inducing settlement, but the stalemate effect would favor the American rule. Unfortunately, until more information is available about the distribution of disputes in terms of the parties' estimates of their probabilities of success and some sense emerges as to the relative strengths of the recognition and stalemate effects, a final assessment of the effect of changing legal rules on the likelihood of settlement will be elusive.

73. See Gordon Tullock, Negotiated Settlement, in J. Matthias Graf von der Schulenburg \& Göran Skogh, eds, Law and Economics $\mathcal{E}$ ' the Economics of Legal Regulation 39-50 (Kluwer Academe, 1987). Professor Tullock identifies only what I call the stalemate effect and thinks it will be very potent in inhibiting settlement. He therefore disagrees with the widely held belief that "the likelihood of settlement is positively related to the width of the settlement zone." Samual Issacharoff \& George Loewenstein, Second Thoughts about Summary Judgment, 100 Yale L J 73, 101 (1990). 
FiguRE 3

Comparison Between American and British

Rules FOR EC $_{B}-E_{A}\left(P_{B}=0.30\right)$

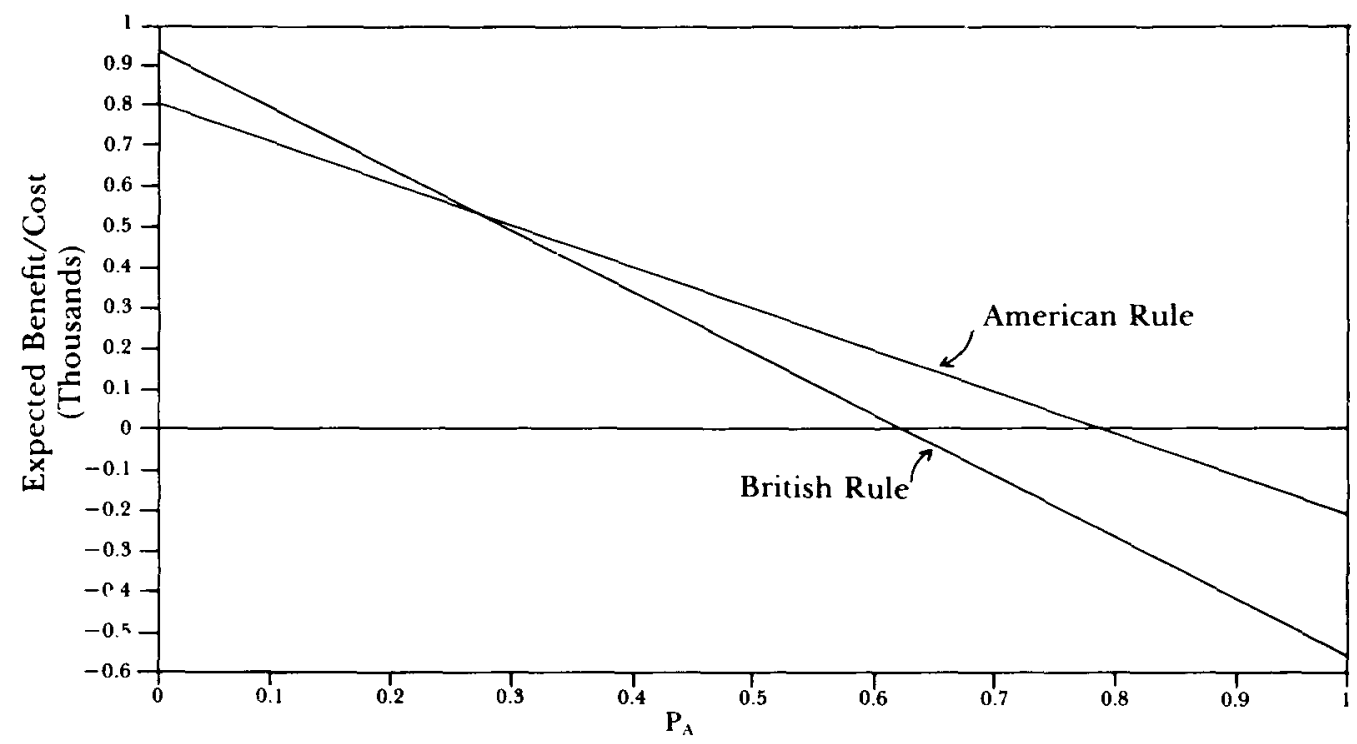

Figure 4

Comparison Between American and British

RULES FOR $\mathrm{EC}_{\mathrm{B}}-\mathrm{EB}_{\mathrm{A}}\left(\mathrm{P}_{\mathrm{B}}=0.5\right)$

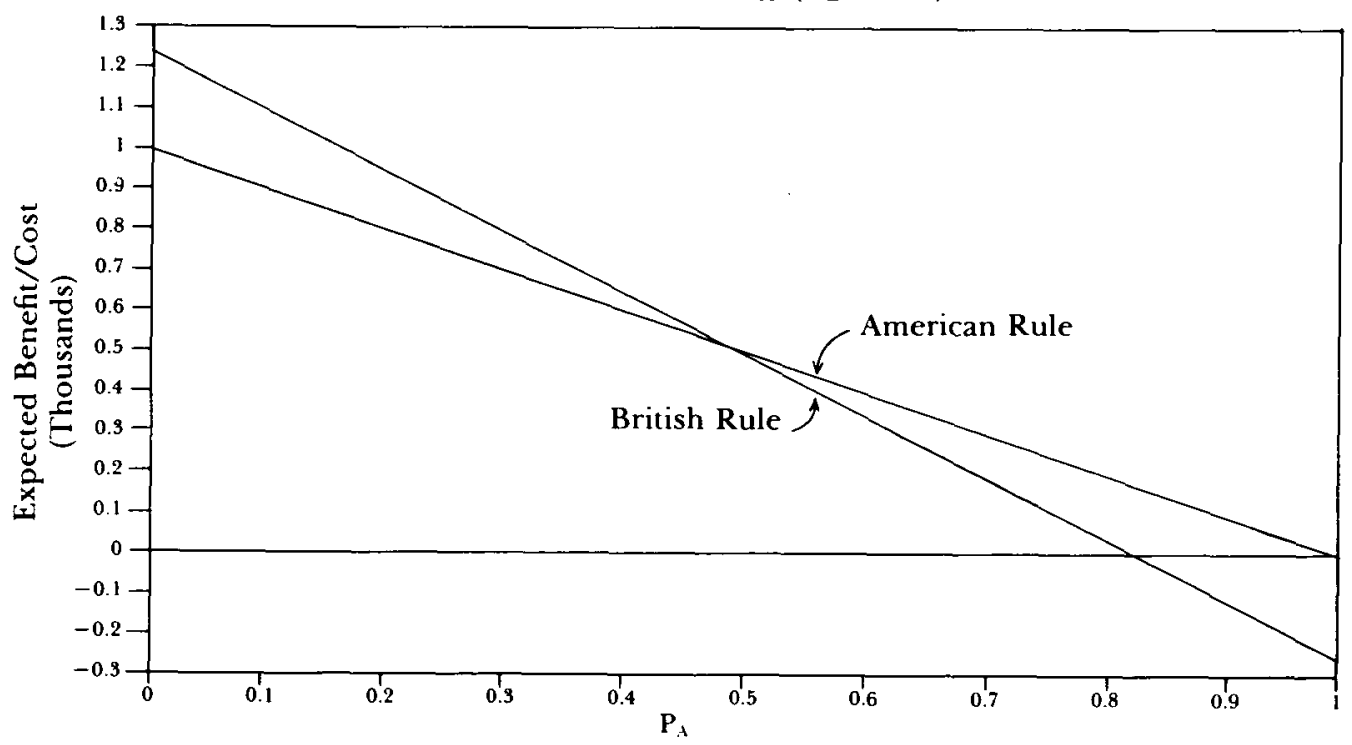


Figure 5

Comparison Between American and British

Rules FOR $\mathrm{EC}_{\mathrm{B}}-\mathrm{EB}_{\mathrm{A}}\left(\mathrm{P}_{\mathrm{B}}=0.7\right)$

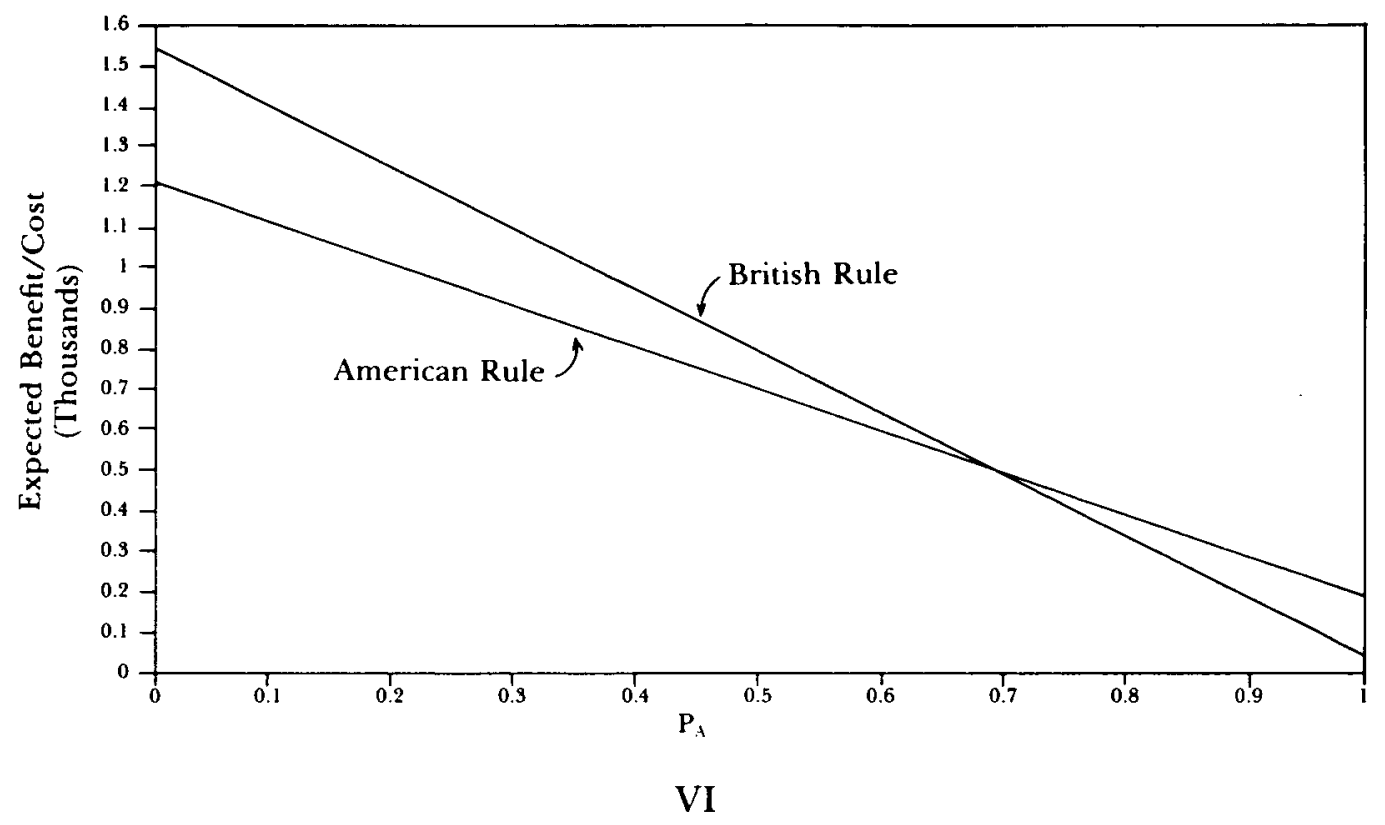

Conclusion

These theoretical observations about various aspects of the decision to litigate or settle a case suggest that some humility is appropriate in attempting to determine the effect of different rules of fee allocation on the likelihood of settlement. The strength of the economic models is that they illustrate factors that may influence the behavior of litigants. But, as is so often the case with theoretical models, the factors that are uncovered frequently have conflicting effects, and the nature of the modelling is very sensitive to institutional details. Are parties free to contract for the cost-allocation rule that they think is preferable? Do they realize this option is available, and can they effect such rule shifts at low cost? If so, then the legal regime should have little or no impact on the settlement rate. If not, then the Posner/Shavell analysis, suggesting that the British rule reduces the likelihood of settlement, becomes significant but by no means dispositive. Risk aversion will cut in the opposite direction, increasing the likelihood of settlement under the British rule. Moreover, the higher stakes of the British rule will also lead to greater expenditures at trial than will occur under the American rule, which also makes settlement more likely with the British rule. Perhaps more importantly, institutional details such as the existence of a contingency fee and the likely impact given the divergence in interests between lawyer and client may be far more significant in affecting the rate of settlement than the rule of fee allocation. 
This entire discussion is of course premised on the view that the traditional law and economics model of the settlement decision is the correct one to begin with, which again is not certain. The assumption that a larger settlement rage will increase the likelihood of settlement may not be true, for once again theoretical reasons exist for thinking that this factor can have competing effects. Even worse, game theoretic models, such as those presented by Barry Nalebuff, frequently reverse even the direction of causation of some of the factors specified in the standard law and economics models. ${ }^{74}$ It may not be surprising, then, that the empirical evidence on the effect of the British rule on the rate of settlement is also conflicting. ${ }^{75}$ Until a better empirical foundation has been established, the existing theoretical arsenal is still too weak to resolve many of the ultimate questions of interest.

74. Barry Nalebuff, Credible Pretrial Negotiation, 18 RAND J Econ 198 (1987).

75. See the studies cited in Donohue, 104 Harv L Rev at $1095 \mathrm{n} 7$ (cited in note 7). 